\title{
Is obesity in women protective against osteoporosis?
}

This article was published in the following Dove Press journal:

Diabetes, Metabolic Syndrome and Obesity:Targets and Therapy 2 July 2011

Number of times this article has been viewed

\author{
Silvia Migliaccio ${ }^{1,2}$ \\ Emanuela A Greco' \\ Rachele Fornari' \\ Lorenzo M Donini' \\ Andrea Lenzi' \\ 'Dipartimento di Medicina \\ Sperimentale, Sezione di \\ Fisiopatologia, Endocrinologia e \\ Nutrizione, Università Sapienza \\ di Roma, ${ }^{2}$ Dipartimento di Scienze \\ della Salute, Università Foro \\ Italico di Roma, Italia
}

Correspondence: Silvia Migliaccio Dipartimento di Medicina Sperimentale, Università Sapienza di Roma,Viale Regina Elena 00 I6I, Roma, Italia

Tel +3906 49970721

Fax +3906 446I 450

Email silvia.migliaccio@uniromal.it

\begin{abstract}
The belief that obesity is protective against osteoporosis has recently come into question. The latest epidemiologic and clinical studies have shown that a high level of fat mass might be a risk factor for osteoporosis and fragility fractures. Further, increasing evidence seems to indicate that different components of the metabolic syndrome, ie, hypertension, increased triglycerides, reduced high-density lipoprotein cholesterol, are also potential risk factors for the development of low bone mineral density and osteoporosis. This review considers both the older and more recent data in the literature in order to evaluate further the relationship between fat tissue and bone tissue.
\end{abstract}

Keywords: bone mineral density, fat mass, body mass index, fractures, adipocytes

\section{Introduction}

Obesity and osteoporosis are two important global health problems with an increasing prevalence and a high impact on both mortality and morbidity. ${ }^{1-4}$ Interestingly, during recent decades, both diseases have become a major health threat worldwide. ${ }^{2}$ Age and female gender increase the risk of developing both obesity and osteoporosis, which affect millions of women. ${ }^{3,5-7}$ Age-related changes in body composition, metabolic factors, and hormonal levels after menopause, accompanied by a decline in physical activity, may all provide mechanisms for the propensity to gain weight and, in particular, for the increase in fat mass often characterized by replacement of lean mass by adipose tissue..$^{3,4}$

Obesity is due to an imbalance in which energy intake exceeds energy expenditure over a prolonged period. ${ }^{2}$ In healthy adults, body weight is tightly regulated despite day-to-day variations in food intake and energy expenditure. Several environmental, nutritional, and hormonal factors appear to influence body weight. ${ }^{1-3}$ For instance, postmenopausal women often show increased body weight, likely due to a decrease in basal metabolism, alteration of hormonal levels, and reduced physical activity. ${ }^{8}$ Moreover, obese postmenopausal women are often affected by hypertension, dyslipidemia, diabetes mellitus, and cardiovascular disease, and have an increased risk of developing some cancers. ${ }^{3,9,10}$ Interestingly, these women have always been considered protected against osteoporosis. ${ }^{5,6,11}$

Osteoporosis is a metabolic bone disease characterized by excessive skeletal fragility (due to a reduction in both bone quantity and quality), leading to an increased risk of developing spontaneous and traumatic bone fractures. ${ }^{7}$ More than $40 \%$ of postmenopausal women, on average, will suffer at least one osteoporosis fracture, often leading 
to permanent and severe disability, nursing home placement, and even death. ${ }^{11,12}$ The rate of bone loss in adults reflects the interaction between genetic and environmental factors, which also influences the extent of bone acquisition during growth, known as peak bone mass. ${ }^{13}$

It is known that fractures in childhood have been associated with alterations in body composition, such as increased adiposity and bone structure, suggesting that these might be the earliest signs of skeletal insufficiency. ${ }^{14}$ Soon after menopause, the process of bone loss begins in women, due to increased bone resorption by osteoclasts, which overcomes bone formation by osteoblasts. ${ }^{13}$ Moreover, osteoblast function declines with aging, determining the imbalance between bone resorption and bone formation. ${ }^{15}$ Traditionally, osteoporosis has been regarded as a disorder associated only with fracture and skeletal disability in old age, but recent studies demonstrate that bone mineral density appears to be a better long-term predictor of death than blood pressure or cholesterol. ${ }^{12,16}$ Further data published in recent decades indicate that low bone mineral density is a strong and independent predictor of all-cause mortality, including cardiovascular mortality. ${ }^{12,16}$

Body fat and lean mass are correlated with bone mineral density, with obesity apparently confering protection against bone loss after menopause. ${ }^{5,6,17}$ The pathophysiological role of adipose tissue in skeletal homeostasis probably lies in the role that several adipokines play in bone remodeling via their effects on either bone formation or resorption. Since the demonstration that bone cells express several specific hormone receptors, the skeleton has come to be considered an endocrine target organ. ${ }^{18-21}$ Additionally, recent observations have shown that bone-derived factors, such as osteocalcin and osteopontin, may affect body weight control and glucose homeostasis, ${ }^{22-24}$ suggesting a possible role of bone tissue as an endocrine organ with the presence of a potential feedback mechanism between the skeleton and endocrine organs. ${ }^{25}$ Thus, the cross-talk between fat and bone likely constitutes a homoeostatic feedback system in which adipokines and molecules secreted by osteoblasts and osteoclasts represent the link of an active bone-adipose axis. However, the mechanism(s) by which all these events occur remains unclear.

\section{Fat and bone correlation: evidence-based observations}

In the last three decades, the association between obesity and osteoporosis has been actively investigated from epidemiological, clinical, and basic research points of view, and common pathophysiological links have been proposed: both obesity and osteoporosis are influenced by genetic and environmental factors, or the interaction between them; aging is associated with both diseases and with a high incidence of bone loss and bone marrow adiposity; bone remodeling and adiposity are both regulated via a complex interplay of adipokines and hormones; and adipocytes and osteoblasts derive from a common progenitor, ie, the mesenchymal stem cell, ${ }^{11}$ as shown in Figure 1.

Extensive data have shown that, in healthy premenopausal and postmenopausal women, total body fat is positively related to bone mineral density, an important and measurable determinant of fracture risk, ${ }^{26-27}$ that high body weight (or body mass index) is correlated with high bone mineral density, and that decreased body weight leads to bone loss. ${ }^{28-32}$ Furthermore, fat mass, the most important index of obesity, has been demonstrated to have a similarly beneficial effect, leading to an increase in bone mass, ${ }^{17,33}$ while a beneficial effect of fat mass on bone mineral density is confirmed in white women but not in white men. ${ }^{34}$

Although these data indicate that obesity exerts a protective effect on bone tissue, more recent studies have described an opposite event. In particular, although cross-sectional and longitudinal studies have shown that bone mass is positively related to body weight and body mass index, there are controversial issues as to whether lean mass or fat mass might be the most important determinant of bone mineral density. ${ }^{6}$ In particular, the evidence suggests an inverse relationship between obesity and osteoporosis depending on how obesity is defined. In the studies where obesity is defined on the basis of body mass index or body weight, obesity appears to act as a protective factor against bone loss and fractures; however, if obesity is considered as a percentage of body fat and distribution, as in the study published by Zhao et al in a Chinese population, ${ }^{11}$ it becomes a risk factor for osteoporosis.

In particular, there are data indicating that women with a high body mass index $\left(25-29.9 \mathrm{~kg} / \mathrm{m}^{2}\right)$ are protected from osteoporosis, but there is increasing evidence conflicting with this observation, suggesting that obesity (body mass index $>30$ ) might actually interfere with bone health. ${ }^{11}$

In accordance with the data reported by Zhao et al, ${ }^{11} \mathrm{Hsu}$ et al showed that matching of Chinese subjects by body mass index, across $5 \mathrm{~kg}$ strata of body weight, revealed a negative relationship between fat and bone mass, and the risk of osteoporosis and nonspinal fractures was significantly higher for subjects with a higher proportion of body fat, independent of body weight. ${ }^{35}$ Our group has recently demonstrated that $37 \%$ of 395 obese adult subjects had significant skeletal changes. 


\section{Mesenchymal cell}

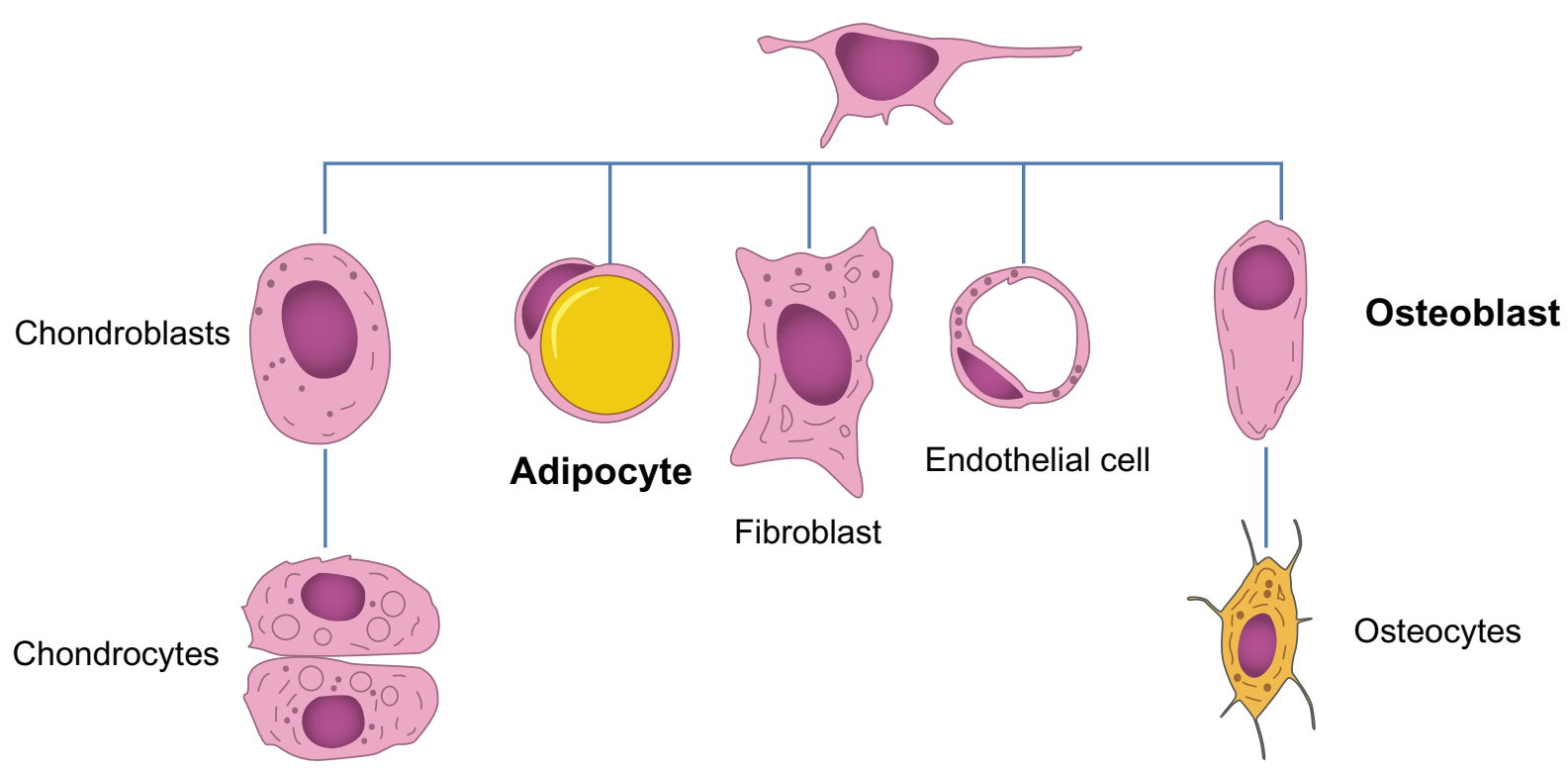

Figure I Several cell lines deriving from a common mesenchymal stem cell. The presence of different stimuli may induce differentiation of the progenitor into one cell line instead of another. However, this event might underscore the presence of a certain degree of plasticity among the cell lineages.

In particular, this subpopulation showed a lower bone mineral density at the lumbar spine than expected for both their young age and high body mass index. ${ }^{36}$ Further characterization showed that different grades of adiposity could affect skeletal health status differently. In fact, stratification of the population into three different groups according to body mass index status, showed a slightly different bone mineral density pattern among the groups. Overweight subjects (body mass index 26-29) did not show any change in skeletal health, while obese and severely obese subjects (body mass index $>30$ ) had significant alteration in their bone mineral density levels, with an increased number of individuals having a lower bone mass than would be expected for their age and body weight. ${ }^{36}$ Evaluation of hormonal, metabolic, and lipid profiles did not show significant differences between the groups, athough more detailed analysis seemed to show higher inflammatory markers and lower levels of circulating vitamin D (Migliaccio et al, unpublished data). Indeed, data published by Blum et al from a cohort of 153 premenopausal women demonstrated that a high amount of fat mass is negatively associated with bone mass. ${ }^{37}$ Thus, all these data suggest an important role for fat distribution as total fat mass itself. A recent study of 907 healthy postmenopausal women by Kim et al demonstrated that body weight was positively related to bone mineral density and vertebral fracture risk, whereas percentage of body fat and waist circumference were related to a low bone mineral density and to a higher risk for vertebral fractures. ${ }^{38}$
Even racial differences appear to influence fat and bone interaction. Castro et al reported that obesity is negatively associated with bone mineral density in black women, but not in white women, ${ }^{39}$ while Afghani and Goran reported an inverse correlation between subcutaneous abdominal adipose tissue and bone mineral density in whites, but not in blacks. In the same study, the authors reported an inverse association between visceral fat and bone mineral density in blacks, but not in whites. ${ }^{40}$ These conflicting results suggest a complex effect of fat mass on bone tissue related to sample size, ethnicity, gender, study design, methods of statistical analysis, and population structure. Nevertheless, several lines of evidence from environmental and medical interventions support an inverse correlation between fat and bone mass, ie, physical exercise increases bone mass while reducing fat mass, ${ }^{41}$ supplementation with calcium and vitamin D appears beneficial for the prevention of both osteoporosis and obesity, ${ }^{42}$ and menopause is also associated with increased fat mass, increased bone loss, and decreased lean mass. ${ }^{43}$ Estrogen replacement therapy in postmenopausal women improves both lean mass and bone mass, and reverses menopauserelated weight gain. ${ }^{44}$ Whereas estrogens reduce the risk of bone loss and obesity, other pharmacological interventions have been shown to increase both osteoporosis and obesity, such as treatment with gonadotropin-releasing hormone agonists and the use of glucocorticoids. ${ }^{45-48}$ Additionally, recent findings have indicated that some antidiabetic drugs, which 
interfere with peroxisome proliferator-activated receptor gamma (PPAR $\gamma$ ) and thus with adipocyte differentiation, also appear to influence skeletal homeostasis and fracture risk significantly.

Thiazolidinedione and other selective PPAR $\gamma$ agonists, such as rosiglitazone and pioglitazone, play a prominent role in the treatment of type 2 diabetic patients. In vitro analyses demonstrate that various PPAR $\gamma$ ligands not only induce murine bone marrow stromal cell adipogenesis, but also inhibit osteogenesis, ${ }^{49}$ and in vivo studies demonstrate that PPAR $\gamma$ agonists reduce bone mineral density and increase fracture rates, notably distal extremity fractures in female type 2 diabetic patients. $^{50}$

\section{Fat and bone correlation: potential mechanisms of interaction}

Several potential mechanisms have been proposed to explain the complex relationship between adipose tissue and bone tissue. Fat has long been viewed as a passive energy reservoir, but since the discovery of leptin and identification of other adipose tissue-derived hormones and serum mediators, ${ }^{51-53}$ fat has come to be considered as an active endocrine organ which modulates energy homeostasis. Adipose tissue also secretes various inflammatory cytokines, including interleukin (IL)-6 and tumor necrosis factor-alpha, ${ }^{54}$ and altered production of these proinflammatory mediators is thought to have adverse metabolic and cardiovascular consequences. All these molecules, which include resistin, leptin, adiponectin, and IL-6, affect human energy homeostasis and may well be involved in bone metabolism, contributing to the complex relationship between adipose tissue and bone tissue (Figure 2). ${ }^{55}$

Fat tissue is one of the major sources of aromatase, an enzyme also expressed in the gonads, which synthesizes estrogens from androgen precursors. Estrogens are steroid hormones which play a pivotal role in the maintenance of skeletal homeostasis, protecting against osteoporosis by reducing bone resorption and stimulating bone formation. This extragonadal estrogen synthesis in fat tissue becomes the dominant estrogen source in postmenopausal women, due to the lack of ovarian function. ${ }^{6}$ Additionally, in obese postmenopausal women, increased estrogen synthesis by adipose tissue has been suggested as one of the potential mechanisms for the protective effect of fat mass on bone.

On the other hand, studies in humans lacking aromatase and in estrogen receptor- $\alpha$ and receptor- $\beta$ knockout mice indicate that estrogens protect against bone loss, and support the hypothesis that these hormones may inhibit the development of obesity, ${ }^{56-61}$ as suggested also by the prevention of

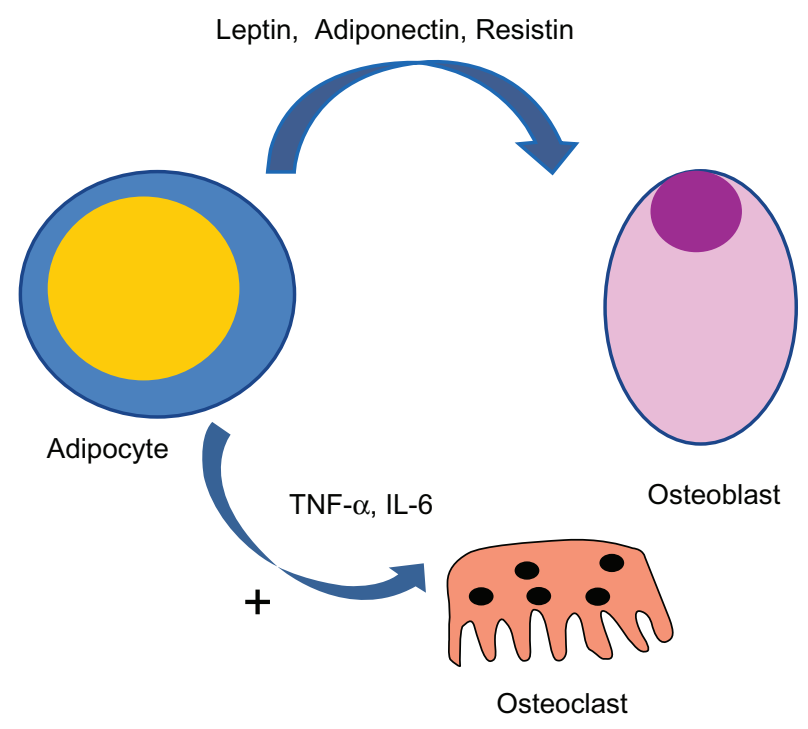

Figure 2 A complex link between adipocytes and bone cell exists. Several cytokines are secreted by fat tissue and act on bone cells. In particular, several proinflammatory cytokines (eg, IL-6 and TNF- $\alpha$ ) act as osteoclastogenic factors with a potentially stimulating mechanism.

Abbreviations: IL-6, interleukin-6; TNF- $\alpha$, tumor necrosis factor alpha.

menopause-induced fat mass gain ${ }^{62-64}$ and reduction of the incidence of osteoporotic fractures by estrogen replacement therapy. ${ }^{65}$ In support of this hypothesis, decreased endogenous estrogen levels have been shown to be coupled with an increase in adipocyte numbers and decreased osteoblast counts in the bone marrow of postmenopausal women. ${ }^{66}$

As mentioned above, several adipokines are involved in the fat-bone interaction. Leptin suppresses appetite, increases energy expenditure, and regulates bone remodeling, and is the most important adipocyte-derived hormone. ${ }^{67-70}$ The effect of leptin on bone is complex, and both negative ${ }^{37,71}$ and positive actions $^{72-74}$ on bone mineral density have been reported in humans. Leptin-deficient ob/ob mice and leptin receptordeficient $\mathrm{db} / \mathrm{db}$ mice are extremely obese, with increased vertebral trabecular bone volume due to increased bone formation, despite hypogonadism and hypercortisolism. ${ }^{69}$ Interestingly, intracerebroventricular infusion of leptin in both ob/ob and wild-type mice was shown to decrease vertebral trabecular bone mass. ${ }^{69}$ In vivo studies indicate that the effect of leptin may depend on its site and mode of action, ${ }^{75-77}$ and it has been proposed that peripheral administration of leptin could increase bone mass by inhibiting bone resorption ${ }^{78}$ and increasing bone formation, ${ }^{52,79}$ while inhibiting bone formation through a central nervous system effect. ${ }^{69}$ In vitro studies also found that leptin can act directly on bone marrow-derived mesenchymal stem cells to enhance their differentiation into osteoblasts and to inhibit their differentiation into adipocytes. ${ }^{79,80}$ 
Takeda et al expanded these observations further, demonstrating that the effects of intracerebroventricular leptin are mediated by the sympathetic nervous system, and that osteoblasts express $\beta$-adrenergic receptors via which it is probable that administration of $\beta$-adrenergic agonists decreases trabecular bone volume by inhibiting bone formation. ${ }^{70}$ Noradrenaline also seems to increase bone resorption by promoting nuclear factor kappa-B ligand expression and inhibiting osteoblast proliferation. ${ }^{81-83}$ The effect of leptin on obesity is mediated via proopiomelanocortin neurons and neuropeptide $\mathrm{Y}^{84}$ Leptin reduces food intake and increases energy expenditure by stimulating proopiomelanocortin neurons to secrete $\alpha$-melanocyte-stimulating hormone,${ }^{85}$ which, in addition to having an effect on obesity, might contribute to bone resorption ${ }^{82}$ but not bone formation..$^{70}$ Interestingly, type $4 \alpha$-melanocyte-stimulating hormone receptor knockout mice have high bone mass due to decreased bone resorption. ${ }^{82}$

Leptin also inhibits expression of neuropeptide Y, a hypothalamus-derived peptide, essential for the regulation of food consumption, energy homeostasis, and bone remodeling. ${ }^{86,87}$ Hypothalamus-specific $N P Y$ knockout mice show a significant decrease in body weight, a significant increase in food intake, and a two-fold increase in trabecular bone volume compared with wild-type animals. ${ }^{88,89}$

Adiponectin is another adipocyte-derived hormone which has anti-inflammatory and antiatherogenic effects, regulating energy homeostasis and bone remodeling. ${ }^{90-94} \mathrm{In}$ contrast with leptin, serum adiponectin levels are reduced in obese and diabetic subjects ${ }^{95}$ and increase after weight loss. ${ }^{92}$ Human osteoblasts express adiponectin and its receptors, ${ }^{92}$ but both negative and positive links between adiponectin and bone mineral density have been reported. ${ }^{96,97}$ Other in vivo and in vitro studies show that adiponectin increases bone mass by suppressing osteoclastogenesis and activating osteoblastogenesis, ${ }^{92-94}$ suggesting that a rise in adiponectin levels caused by fat reduction could have a beneficial effect on bone mineral density.

Thommesen et al showed that resistin may play a role in bone remodeling, indicating that it is expressed in mesenchymal stem cells, osteoblasts, and osteoclasts in bone marrow. Resistin increases osteoblast proliferation and cytokine release, as well as osteoclast differentiation, ${ }^{98}$ so the effect of resistin on bone is still unclear, and further studies are needed to understand its role better.

IL-6 is a pluripotent inflammatory cytokine, released from adipocytes, adipose tissue matrix, osteoblast, and elsewhere in the body ${ }^{99}$ In particular, adipose tissue accounts for onethird of circulating levels of IL-6. Obese subjects have high circulating levels of this proinflammatory cytokine, ${ }^{100,101}$ and genetic polymorphism of IL-6 is associated with obesity. ${ }^{102}$ Moreover, peripheral administration of IL-6 induces hyperlipidemia, hyperglycemia, and insulin resistance in rodents and humans. ${ }^{103}$ In contrast, administration of IL-6 in the central nervous system increases energy expenditure and decreases body fat in rodents. ${ }^{103} \mathrm{IL}-6$ is also a well recognized stimulator of osteoclastogenesis and bone resorption ${ }^{104,105}$ but some data show that IL-6 mRNA is expressed in preosteoblasts and osteoblasts, ${ }^{106}$ and that IL-6 stimulates osteoblast proliferation and differentiation ${ }^{107}$ by controlling the production of local factors, ${ }^{108}$ and it might play a role in bone formation in conditions of high bone turnover. ${ }^{108,109}$

In addition to adipocytes, adipose tissue contains various stromal and vascular cells, including fibroblasts, vascular endothelial cells, and inflammatory cells. Adipocytes were initially thought to be the major source of adipose-derived mediators, but recent studies have shown that macrophages infiltrate adipose tissue, and that these macrophages, along with other cells that reside in the stroma, also contribute to the production and secretion of humoral mediators, particularly inflammatory cytokines. ${ }^{54} \mathrm{~A}$ paracrine loop involving free fatty acids and inflammatory cytokines has been postulated to establish a vicious cycle between adipocytes and macrophages, thereby propagating inflammation. ${ }^{110,111}$ Therefore, it is important to define interactions between adipocytes, osteoblasts, and stromal cells in obese subjects.

\section{Adipocytes and osteoblasts: a common origin}

Adipocytes and osteoblasts originate from a common progenitor, ie, a pluripotential mesenchymal stem cell, ${ }^{112}$ which has an equal propensity for differentiation into adipocytes or osteoblasts (or other lines) under the influence of several cell-derived transcription factors. This process is complex, suggesting significant plasticity and multifaceted mechanism(s) of regulation within different cell lineages, among which are adipocytes and osteoblasts. ${ }^{113,114}$ Several studies have examined the function of adipocytes in bone marrow. Mesenchymal stem cells isolated from marrow in postmenopausal osteoporotic patients express more adipose differentiation markers than those from subjects with normal bone mass. ${ }^{115}$

As mentioned earlier, adipocytes secrete endocrine and paracrine factors that strongly influence bone differentiation and remodeling. Estrogens are among these factors, explaining why increased body weight in postmenopausal women is associated with slower rates of bone loss. ${ }^{113,116,117}$ However, 
the interaction between estrogens and fat appears to be complex. Martin and Zissimos showed pronounced fatty infiltration in the bone marrow of rats following oophorectomy, suggesting a pivotal role of estrogen in regulating adipocyte recruitment. ${ }^{118}$ On the other hand, the presence of aromatase in fat cells allows higher intramarrow conversion of testosterone into estrogens which, in turn, can inhibit bone resorption. ${ }^{113}$

The effect of estrogen on bone and adipose tissue formation has long been recognized in experimental animal models. ${ }^{118,119}$ In humans, changes in estrogen status due to advancing age and menopause have been correlated with increased levels of IL-6 and IL-11, which are both associated with bone loss. ${ }^{120}$ It is interesting to speculate whether the increase in adipogenesis subsequent to menopause is due to a relief of repression or to an induction of the adipogenic phenotype, even though in vitro data suggest that the default "switch" might be adipogenesis, a process which might normally be inhibited in vivo prior to estrogen depletion..$^{24}$

Other members of the nuclear hormone receptor family contribute to control of adipogenesis and osteogenesis. PPAR $\gamma$ plays a central role in initiating adipogenesis. ${ }^{113}$ Mutations of the PPAR $\gamma$ gene are associated with an altered balance between bone and fat formation in the bone marrow. The nuclear hormone receptor family of transcriptional regulatory proteins is activated by a range of ligands, including steroid hormones, naturally occurring metabolites, synthetic chemicals, and as yet unidentified endogenous compounds (orphan receptors).

Thiazolidinedione and other PPAR $\gamma$ ligands, such as rosiglitazone and pioglitazone, play a prominent role in the treatment of type 2 diabetes. However, in vitro analyses demonstrate that various PPAR $\gamma$ ligands not only induce murine bone marrow stromal cell adipogenesis but also inhibit osteogenesis. ${ }^{49}$ In particular, PPAR $\gamma-2$ is the dominant regulator of adipogenesis, and ligand activation of PPAR $\gamma-2$ favors differentiation of mesenchymal stem cells into adipocytes rather than into osteoblasts. ${ }^{116}$ Akune et al showed that PPAR $\gamma$ insufficiency led to increased osteoblastogenesis in vitro and higher trabecular bone volume in vivo, confirming the key role of mesenchymal stem cell lineage allocation in the skeleton. ${ }^{112}$ Interestingly, aged mice exhibit fat infiltration into bone marrow and enhanced expression of PPAR $\gamma-2$, along with reduced mRNA expression of bone differentiation factors. ${ }^{121}$ Mice with premature aging (the SAM-P/6 model) show nearly identical patterns of adipocyte infiltration, with impaired osteoblastogenesis, ${ }^{122}$ indicating that aging, or events that accelerate aging, result in significant bone marrow adiposity and a defect in osteoblastogenesis in mice. ${ }^{123}$

The Wnt signaling pathway works in a coordinated manner with other transmembrane signals, including multiple ligands, antagonists, receptors, coreceptors, and transcriptional mediators, such as $\beta$-catenin. ${ }^{124}$ Specific elements of the Wnt signaling pathway have been found to inhibit adipogenesis ${ }^{125,126}$ while promoting osteogenesis. ${ }^{127-131} \mathrm{Wnt}$ inhibition of adipogenesis is mediated via $\beta$-catenin, which interferes with PPAR $\gamma$ transcriptional activation of downstream targets. ${ }^{132}$ Following exposure to transforming growth factor beta, human bone marrow mesenchymal stem cells increase their expression of various Wnt receptors and ligands. ${ }^{133}$

Members of the epidermal growth factor family, such as protein Pref-1, influence both adipogenesis and osteogenesis. In vitro analysis of human bone marrow mesenchymal stem cells has shown that Pref-1 overexpression blocks both adipogenesis and osteogenesis. This finding is consistent with the hypothesis that Pref-1 maintains mesenchymal stem cells in a multipotent state. ${ }^{134}$

Further experimental tools, such as gene microarrays, are being used to document the relationship between classical steroid hormones and bone and fat formation in the marrow. One study has examined the skeletal phenotype of mice deficient in both thyroid receptors $\alpha$ and $\beta$. These mice showed increased mRNA levels for adipocyte-specific genes, increased numbers of bone marrow adipocytes, and reduced trabecular and total bone mineral density. ${ }^{135}$ The inbred SAM-P/6 murine strain provides a model of accelerated senescence characterized by osteopenia and increased fat mass in bone marrow. ${ }^{136}$ Recent studies have found that $1,25(\mathrm{OH}) 2$ vitamin $\mathrm{D}$ treatment inhibits adipogenesis and enhances osteogenesis in SAM-P/6 mice, with a 50\% reduction in PPAR $\gamma$ mRNA and protein levels. ${ }^{123}$ Moreover, gene microarray analyses demonstrated coordinated induction of osteoblastogenic genes and a reduction of adipogenic genes after 1,25 $(\mathrm{OH}) 2$ vitamin D treatment, which stimulates not only bone formation but also bone resorption, according to circulating biomarkers of bone turnover. ${ }^{137}$ Overall, these recent findings involving classical steroid receptors support the inverse relationship between adipogenic and osteogenic differentiation in the bone marrow microenvironment. This is mediated, in part, by cross-talk between the pathways activated by steroid receptors, PPARs, and other cytokines and paracrine factors.

Finally, other factors, such as total caloric intake, type of nutrients, alcohol consumption, oxygen tension, and cellular oxidation-reduction pathways influence bone marrow 
adipogenesis despite osteoblastogenesis, ${ }^{24}$ showing that the bone marrow mesenchymal stem cell may consider multiple differentiation pathways during its lifetime and, indeed, may dedifferentiate and transdifferentiate in response to changes in the microenvironment.

\section{Conclusion}

Obesity and osteoporosis are two major global health problems with an increasing prevalence and a high impact on mortality and morbidity. Menopause is characterized by the cessation of ovarian estrogen production and is associated with increased bone loss, increased fat mass, and decreased lean mass. Age-related changes in hormone levels, in association with changes in body composition, metabolic factors, and decreased physical activity, probably provide the mechanisms for the propensity to postmenopausal gain of fat mass, and thus increased body weight. Estrogen synthesis in adipose tissue, through aromatase, becomes the dominant estrogen source in postmenopausal women. In particular, in obese postmenopausal women, increased estrogen synthesis by fat tissue has been suggested as one of the potential mechanisms for the protective effect of fat mass on bone.

Even though there are data indicating that women with high body mass index are protected from osteoporosis, increasing evidence seems to show conflicting results regarding this issue, suggesting that obesity might actually interfere with bone health. In particular, the relationship between obesity and osteoporosis depends on how obesity is defined. If obesity is defined on the basis of body mass index or body weight, it appears to protect against bone loss and fractures. However, if obesity is based on the percentage of body fat, it may be a risk factor for osteoporosis.

The existence of a cross-talk between fat and the skeleton suggests a homoeostatic feedback system in which adipokines and bone-derived molecules form part of an active boneadipose axis. However, the mechanism(s) by which all these events occur remains unclear. Of course, further basic science research and epidemiological studies with large sample sizes, robust study design, and careful data analysis will be needed to show the true effect of fat mass on bone.

The relationship between fat mass and bone is confounded by complex genetic backgrounds and by interactions between metabolic factors and regulatory pathways influencing both obesity and osteoporosis. Although the evidence that adipose tissue exerts a protective effect against bone loss is greater than that showing a negative association, the recent increasing data on this issue suggest that both obese and nonobese postmenopausal women should be considered at risk for alteration in bone mineral density and osteoporosis. Specific and careful characterization of skeletal metabolism and further studies evaluating skeleton changes may be useful in obese women, because aging itself might also increase their risk of developing fractures later in life.

\section{Disclosure}

The authors report no conflicts of interest in this work.

\section{References}

1. Kado DM, Huang MH, Karlamangla AS, Barrett-Connor E, Greendale GA. Hyperkyphotic posture predicts mortality in older community-dwelling men and women: a prospective study. JAm Geriatr Soc. 2004;52:1662-1667.

2. Rossner S. Obesity: the disease of the twenty-first century. Int $J$ Obes Relat Metab Disord. 2002;26 Suppl 4:S2-S4.

3. Hu FB. Overweight and obesity in women: health risks and consequences. J Women Health (Larchmt). 2003;12(2):163-172.

4. Obesity: preventing and managing the global epidemic. Report of a WHO consultation. World Health Organ Tech Rep Ser. 2000;894:1-253.

5. Albala C, Yanez M, Devoto E, Sostin C, Zeballos L, Santos JL. Obesity as a protective factor for postmenopausal osteoporosis. Int J Obes Relat Metab Disord. 1996;20:1027-1032.

6. Reid IR. Relationships among body mass, its components, and bone Bone. 2002;31:547-555.

7. NIH. Consensus development panel on osteoporosis. JAMA. 2001;285 785-795.

8. Cagnacci A, Zanin R, Cannoletta M, Generali M, Caretto S, Volpe A. Menopause, estrogens, progestin, or their combination on body weight and anthropometric measurements. Fertil Steril. 2007;88(6): 1603-1608.

9. Lebovitz HE. The relationship of obesity to the metabolic syndrome. Int J Clin Pract Suppl. 2003;134:18-27.

10. Sowers JR. Obesity as a cardiovascular risk factor. Am J Med. 2003;8: 37S-41S.

11. Zhao LJ, Jiang H, Papasian CJ, et al. Correlation of obesity and osteoporosis: effect of fat mass on the determination of osteoporosis. J Bone Miner Res. 2008;23:17-29.

12. Johansson C, Black D, Johnell O, Oden A, Mellstrom D. Bone mineral density is a predictor of survival. Calcif Tissue Int. 1998;63:190-196.

13. Brown S, Rosen CJ. Osteoporosis. Med Clin North Am. 2003;87: 1039-1063.

14. Goulding A, Jones IE, Taylor RW, Williams SM, Manning PJ. Bone mineral density and body composition in boys with distal forearm fractures: a dual-energy X-ray absorptiometry study. J Pediatr. 2001; 139:509-515.

15. Kveiborg M, Flyvbjerg A, Rattan SI, Kassem M. Changes in the insulinlik growth factor-system may contribute to in vitro agerelate impaired osteoblast functions. Exp Geronto. 2000;35:1061-1074.

16. Von der Recke P, Hansen MA, Hassager C. The association between low bone mass at the menopause and cardiovascular mortality. Am J Med. 1999;106:273-278.

17. Reid IR, Plank LD, Evans MC. Fat mass is an important determinant of whole body bone density in premenopausal women but not in men. J Clin Endoc Metab. 1992;75:779-782.

18. Eriksen EF, Colvard DS, Berg NJ, et al. Evidence of estrogen receptors in normal human osteoblast-like cells. Science. 1988 1;241(4861): $84-86$

19. Kim HJ. New understanding of glucocorticoid action in bone cells BMB Rep. 2010;43(8):524-529.

20. Komm BS, Terpening CM, Benz DJ, et al. Estrogen binding, receptor mRNA, and biologic response in osteoblast-like osteosarcoma cells. Science. 1988;241(4861):81-84. 
21. Migliaccio S, Davis VL, Gibson MK, Gray TK, Korach KS. Estrogens modulate the responsiveness of osteoblast-like cells (ROS 17/2.8) stably transfected with estrogen receptor. Endocrinology. 1992;130(5): 2617-2624.

22. Gomez-Ambrosi J, Rodriguez A, Catalan V, Fruhbeck G. The bone-adipose axis in obesity and weight loss. Obes Surg. 2008;18:1134-1143.

23. Takeda S. Effect of obesity on bone metabolism. Clin Calcium. 2008;18: 632-637.

24. Gimble JM, Zvonic S, Floyd ZE, Kassem M, Nuttall ME. Playing with bone and fat. $J$ Cell Biochem. 2006;98:251-266.

25. Fukumoto S, Martrin TJ. Bone as an endocrine organ. Trends Endocrinol Metab. 2009;20(5):230-236.

26. Cummings SR, Black DM, Nevitt MC, et al. Bone density at various sites for prediction of hip fractures. The Study of Osteoporotic Fractures Research Group. Lancet. 1993;341:72-75.

27. Melton LJ III, Atkinson EJ, O'Fallon WM, Wahner HW, Riggs BL. Long-term fracture prediction by bone mineral assessed at different skeletal sites. J Bone Miner Res. 1993;8:1227-1233.

28. Mazess RB, Barden HS, Ettinger M, et al. Spine and femur density using dual-photon absorptiometry in US white women. Bone Miner Res. 1987;2:211-219.

29. Felson DT, Zhang Y, Hannan MT, Anderson JJ. Effects of weight and body mass index on bone mineral density in men and women: The Framingham study. J Bone Miner Res. 1993;8:567-573.

30. Marcus R, Greendale G, Blunt BA, et al. Correlates of bone mineral density in the postmenopausal estrogen/progestin interventions trial. J Bone Miner Res. 1994;9:1467-1476.

31. Reid IR, Ames R, Evans MC, et al. Determinants of total body and regional bone mineral density in normal postmenopausal women - a key role for fat mass. J Clin Endocrinol Metab. 1992;75:45-51.

32. Ravn P, Cizza G, Bjarnason NH, Thompson D et al. Low body mass index is an important risk factor for low bone mass and increased bone loss in early postmenopausal women. Early Postmenopausal Intervention Cohort (EPIC) study group. J Bone Miner Res. 1999;14:1622-1627.

33. Khosla S, Atkinson EJ, Riggs BL, Melton LJ III. Relationship between body composition and bone mass in women. J Bone Miner Res. 1996;11: 857-863.

34. Pluijm SM, Visser M, Smit JH, Popp-Snijders C, Roos JC, Lips P. Determinants of bone mineral density in older men and women: Body composition as mediator. J Bone Miner Res. 2001;16:2142-2151.

35. Hsu YH, Venners SA, Terwedow HA, et al. Relation of body composition, fat mass, and serum lipids to osteoporotic fractures and bone mineral density in Chinese men and women. Am J Clin Nutr. 2006;83: $146-154$.

36. Greco EA, Fornari R, RossiF et al. Is obesity protective for osteoporosis? Evaluation of bone mineral density in individuals with high body mass index. Int J Clin Pract. 2010;64(6):817-820.

37. Blum M, Harris SS, Must A, et al. Leptin, body composition and bone mineral density in premenopausal women. Calcif Tissue Int. 2003;73: $27-32$.

38. Kim KC, Shin DH, Lee SY, et al. Relation between Obesity and Bone Mineral Density and Vertebral Fractures in Korean Postmenopausal Women. Yonsei Med J. 2010;51(6):857-863.

39. Castro JP, Joseph LA, Shin JJ, et al. Differential effect of obesity on bone mineral density in White, Hispanic and African American women: A cross sectional study. Nutr Metab (Lond). 2005;2:9.

40. Afghani A, Goran MI. Racial differences in the association of subcutaneous and visceral fat on bone mineral content in prepubertal children. Calcif Tissue Int. 2006;79:383-388.

41. Reid IR, Legge M, Stapleton JP, Evans MC, Grey AB. Regular exercise dissociates fat mass and bone density in premenopausal women. $J$ Clin Endocrinol Metab. 1995;80:1764-1768.

42. Reid IR. Therapy of osteoporosis: Calcium, vitamin D, and exercise. Am J Med Sci. 1996;312:278-286.

43. Manson JE, Martin KA. Postmenopausal hormonereplacement therapy. N Engl J Med. 2001;345:34-40.
44. Sorensen MB, Rosenfalck AM, Hojgaard L, Ottesen B. Obesity and sarcopenia after menopause are reversed by sex hormone replacement therapy. Obes Res. 2001;9:622-626.

45. De Gregorio LH, Lacativa PG, Melazzi AC, Russo LA. Glucocorticoid-induced osteoporosis. Arq Bras Endocrinol Metabol. 2006;50:793-801.

46. Steinbuch M, Youket TE, Cohen S. Oral glucocorticoid use is associated with an increased risk of fracture. Osteoporos Int. 2004;15: 323-328

47. Gaillard D, Wabitsch M, Pipy B, Negrel R. Control of terminal differentiation of adipose precursor cells by glucocorticoids. J Lipid Res. 1991;32:569-579.

48. Livingstone DE, Jones GC, Smith K, et al. Understanding the role of glucocorticoids in obesity: Tissue-specific alterations of corticosterone metabolism in obese Zucker rats. Endocrinology. 2000;141: $560-563$.

49. Lecka-Czernik B, Moerman EJ, Grant DF, Lehmann JM, Manolagas SC, Jilka RL. Divergent effects of selective peroxisome proliferatoractivated receptor-gamma 2 ligands on adipocyte versus osteoblast differentiation. Endocrinology. 2002;143:2376-2384.

50. Riche DM, Travis King S. Bone loss and fractures risk associated with thiazolidinedione therapy. Endocrinology. 2007;148(6):2669-2680.

51. Kadowaki T, Yamauchi T. Adiponectin and adiponectin receptors. Endocr Rev. 2005;26:439-451.

52. Steppan CM, Crawford DT, Chidsey-Frink KL, Ke H, Swick AG. Leptin is a potent stimulator of bone growth in ob/ob mice. Regul Pept. 2000; 92:73-78.

53. Vendrell J, Broch M, Vilarrasa N, et al. Resistin, adiponectin, ghrelin, leptin, and proinflammatory cytokines: Relationships in obesity. Obes Res. 2004;12:962-971.

54. Tilg H, Moschen AR. Inflammatory mechanisms in the regulation of insulin resistance. Mol Med. 2008;14(3-4):222-231.

55. Magni P, Dozio E, Galliera E, Ruscica M, Corsi MM. Molecular Aspects of Adipokine-Bone Interactions. Curr Mol Med. 2010;10(6): 522-532.

56. Wade GN, Gray JM, Bartness TJ. Gonadal influences on adiposity. Int J Obes Relat Metab Disord. 1985;9(Suppl 1):83-92.

57. Smith EP, Boyd J, Frank GR, et al. Estrogen resistance caused by a mutation in the estrogen receptor gene in a man. N Engl J Med. 1994;331: $1056-1061$

58. Morishima A, Grumbach MM, Simpson ER, Fisher C, Qin K. Aromatase deficiency in male and female siblings caused by a novel mutation and the physiological role of estrogens. J Clin Endocrinol Metab. 1995;80:3689-3698.

59. Heine PA, Taylor JA, Iwamoto GA, Lubahn DB, Cooke PS. Increased adipose tissue in male and female estrogen receptor-alpha knockout mice. Proc Natl Acad Sci U S A. 2000;97:12729-12734.

60. Cooke PS, Heine PA, Taylor JA, Lubahn DB. The role of estrogen and estrogen receptor-alpha in male adipose tissue. Mol Cell Endocrinol. 2001;178:147-154.

61. Maffei L, Murata Y, Rochira V, et al. Dysmetabolic syndrome in a man with a novel mutation of the aromatase gene: Effects of testosterone, alendronate, and estradiol treatment. J Clin Endocrinol Metab. 2004;89: 61-70.

62. Tchernof A, Calles-Escandon J, Sites CK, Poehlman ET. Menopause, central body fatness, and insulin resistance: Effects of hormone-replacement therapy. Coron Artery Dis. 1998;9: 503-511.

63. Gambacciani M, Ciaponi M, Cappagli B, De Simone L, Orlandi R, Genazzani AR. Prospective evaluation of body weight and body fat distribution in early postmenopausal women with and without hormonal replacement therapy. Maturitas. 2001;39:125-132.

64. Jensen LB, Vestergaard P, Hermann AP, et al. Hormone replacement therapy dissociates fat mass and bone mass, and tends to reduce weight gain in early postmenopausal women: A randomized controlled 5-year clinical trial of the Danish Osteoporosis Prevention Study.J Bone Miner Res. 2003;18:333-342. 
65. Rossouw JE, Anderson GL, Prentice RL, et al. Risks and benefits of estrogen plus progestin in healthy postmenopausal women: Principal results From the Women's Health Initiative randomized controlled trial. JAMA. 2002;288:321-333.

66. Justesen J, Stenderup K, Ebbesen EN, Mosekilde L, Steiniche T, Kassem M. Adipocyte tissue volume in bone marrow is increased with aging and in patients with osteoporosis. Biogerontology. 2001;2:165-171.

67. Zhang Y, Proenca R, Maffei M, Barone M, Leopold L, Friedman JM Positional cloning of the mouse obese gene and its human homologue. Nature. 1994;372:425-432.

68. Mantzoros CS. The role of leptin in human obesity and disease: A review of current evidence. Ann Intern Med. 1999;130:671-680.

69. Ducy P, Amling M, Takeda S, et al. Leptin inhibits bone formation through a hypothalamic relay: A central control of bone mass. Cell. 2000;100:197-207.

70. Takeda S, Elefteriou F, Levasseur R, et al. Leptin regulates bone formation via the sympathetic nervous system. Cell. 2002;111:305-317.

71. Kontogianni MD, Dafni UG, Routsias JG, Skopouli FN. Blood leptin and adiponectin as possible mediators of the relation between fat mass and BMD in perimenopausal women. J Bone Miner Res. 2004;19:546-551.

72. Goulding A, Taylor RW. Plasma leptin values in relation to bone mass and density and to dynamic biochemical markers of bone resorption and formation in postmenopausal women. Calcif Tissue Int. 1998;63: 456-458.

73. Yamauchi M, Sugimoto T, Yamaguchi T, et al. Plasma leptin concentrations are associated with bone mineral density and the presence of vertebral fractures in postmenopausal women. Clin Endocrinol (Oxf). 2001;55:341-347.

74. Pasco JA, Henry MJ, Kotowicz MA, et al. Serum leptin levels are associated with bone mass in nonobese women. J Clin Endocrinol Metab. 2001;86:1884-1887.

75. Thomas T, Burguera B. Is leptin the link between fat and bone mass? J Bone Miner Res. 2002;17:1563-1569.

76. Thomas T. Leptin: A potential mediator for protective effects of fat mass on bone tissue. Joint Bone Spine. 2003;70:18-21.

77. Thomas T. The complex effects of leptin on bone metabolism through multiple pathways. Curr Opin Pharmacol. 2004;4:295-300.

78. Martin A, de Vittoris R, David V, et al. Leptin modulate both resorption and formation while preventing disuse-induced bone loss in tailsuspended female rats. Endocrinology. 2005;146(8):3652-3659.

79. Cornish J, Callon KE, Bava U, et al. Leptin directly regulates bone cell function in vitro and reduces bone fragility in vivo. J Endocrinol. 2001 175:405-415.

80. Thomas T, Gori F, Khosla S, Jensen MD, Burguera B, Riggs BL. Leptin acts on human marrow stromal cells to enhance differentiation to osteoblasts and to inhibit differentiation to adipocytes. Endocrinology. 1999;140:1630-1638.

81. Fu L, Patel MS, Bradley A, Wagner EF, Karsenty G. The molecular clock mediates leptin-regulated bone formation. Cell. 2005;122:803-815.

82. Elefteriou F, Ahn JD, Takeda S, et al. Leptin regulation of bone resorption by the sympathetic nervous system and CART. Nature. 2005;434: 514-520.

83. Karsenty G. Convergence between bone and energy homeostases: Leptin regulation of bone mass. Cell Metab. 2006;4:341-348.

84. Friedman JM, Halaas JL. Leptin and the regulation of body weight in mammals. Nature. 1998;395:763-770.

85. Wisse BE, Schwartz MW. Role of melanocortins in control of obesity. Lancet. 2001;358:857-859.

86. Herzog H. Neuropeptide Y and energy homeostasis: Insights from Y receptor knockout models. Eur J Pharmacol. 2003;480:21-29.

87. Liu YJ, Araujo S, Recker RR, Deng HW. Molecular and genetic mechanisms of obesity: Implications for future management. Curr Mol Med. 2003;3:325-340.

88. Sainsbury A, Schwarzer C, Couzens M, et al. Important role of hypothalamic $\mathrm{Y} 2$ receptors in body weight regulation revealed in conditional knockout mice. Proc Natl Acad Sci U S A. 2002;99:8938-8943.
89. Baldock PA, Sainsbury A, Couzens M, et al. Hypothalamic Y2 receptors regulate bone formation. J Clin Invest. 2002;109:915-921.

90. Combs TP, Berg AH, Obici S, Scherer PE, Rossetti L. Endogenous glucose production is inhibited by the adiposederived protein Acrp30. J Clin Invest. 2001;108:1875-1881.

91. Berg AH, Combs TP, Du X, Brownlee M, Scherer PE. The adipocytesecreted protein Acrp30 enhances hepatic insulin action. Nat Med. 2001;7:947-953.

92. Berner HS, Lyngstadaas SP, Spahr A, et al. Adiponectin and its receptors are expressed in bone-forming cells. Bone. 2004;35:842-849.

93. Oshima K, Nampei A, Matsuda M, et al. Adiponectin increases bone mass by suppressing osteoclast and activating osteoblast. Biochem Biophys Res Commun. 2005;331:520-526.

94. Luo XH, Guo LJ, Yuan LQ, et al. Adiponectin stimulates human osteoblasts proliferation and differentiation via the MAPK signaling pathway. Exp Cell Res. 2005;309:99-109.

95. Weyer C, Funahashi T, Tanaka S, et al. Hypoadiponectinemia in obesity and type 2 diabetes: Close association with insulin resistance and hyperinsulinemia. J Clin Endocrinol Metab. 2001;86:1930-1935.

96. Lenchik L, Register TC, Hsu FC et al. Adiponectin as a novel determinant of bone mineral density and visceral fat. Bone. 2003;33:646-651.

97. Jurimae J, Rembel K, Jurimae T, Rehand M. Adiponectin is associated with bone mineral density in perimenopausal women. Horm Metab Res. 2005;37:297-302.

98. Thommesen L, Stunes AK, Monjo M, et al. Expression and regulation of resistin in osteoblasts and osteoclasts indicate a role in bone metabolism. J Cell Biochem. 2006;99(3): 824-834.

99. Fain JN, Madan AK, Hiler ML, Cheema P, Bahouth SW. Comparison of the release of adipokines by adipose tissue, adipose tissue matrix, and adipocytes from visceral and subcutaneous abdominal adipose tissues of obese humans. Endocrinology. 2004;145:2273-2282.

100. Fernandez-Real JM, Ricart W. Insulin resistance and chronic cardiovascular inflammatory syndrome. Endocr Rev. 2003;24:278-301.

101. Das UN. Is obesity an inflammatory condition? Nutrition. 2001;17:953-966.

102. Berthier MT, Paradis AM, Tchernof A. The interleukin 6-174G/C polymorphism is associated with indices of obesity in men. $\mathrm{J} \mathrm{Hum}$ Genet. 2003;48:14-19.

103. Kershaw EE, Flier JS. Adipose tissue as an endocrine organ. J Clin Endocrinol Metab. 2004;89:2548-2556.

104. Richards CD, Langdon C, Deschamps P, Pennica D, Shaughnessy SG. Stimulation of osteoclast differentiation in vitro by mouse oncostatin $\mathrm{M}$, leukaemia inhibitory factor, cardiotrophin-1 and interleukin 6: Synergy with dexamethasone. Cytokine. 2000;12:613-621.

105. Rodan GA. Introduction to bone biology. Bone. 1992;13(Suppl 1): $\mathrm{S} 3-\mathrm{S} 6$.

106. Dodds RA, Merry K, Littlewood A, Gowen M. Expression of mRNA for IL1 beta, IL6 and TGF beta 1 in developing human bone and cartilage. J Histochem Cytochem. 1994;42:733-744

107. Taguchi Y, Yamamoto M, Yamate T, et al. Interleukin-6-type cytokines stimulate mesenchymal progenitor differentiation toward the osteoblastic lineage. Proc Assoc Am Physicians. 1998;110:559-574.

108. Franchimont N, Wertz S, Malaise M 2005 Interleukin-6: An osteotropic factor influencing bone formation? Bone 37:601-606. Sims NA, Jenkins BJ, Quinn JM, Nakamura A, Glatt M, Gillespie MT, Ernst M, Martin TJ. 2004 Glycoprotein 130 regulates bone turnover and bone size by distinct downstream signaling pathways. J Clin Invest. 113:379-389.

109. Sims NA, Jenkins BJ, Quinn JM, et al. Glycoprotein 130 regulates bone turnover and bone size by distinct downstream signaling pathways. J Clin Invest. 2004;113:379-389.

110. Suganami T, Nishida J, Ogawa Y. A paracrine loop between adipocytes and macrophages aggravates inflammatory changes: Role of free fatty acids and tumor necrosis factor $\alpha$. Arterioscler Thromb Vasc Biol. 2005;25(10):2062-2068. 
111. Nishimura S, Manabe I, Nagai R. Adipose tissue inflammation in obesity and metabolic syndrome. Discov Med. 2009 Aug;8(41):55-60.

112. Akune T, Ohba S, Kamekura S, et al. PPAR $\gamma$ insufficiency enhances osteogenesis through osteoblast formation from bone marrow progenitors. J Clin Invest. 2004;113:846-855.

113. Gimble JM, Robinson CE, Wu X, et al. Peroxisome proliferatoractivated receptor-gamma activation by thiazolidinediones induces adipogenesis in bone marrow stromal cells. Mol Pharmacol. 1996;50: 1087-1094.

114. Rodriguez JP, Montecinos L, Rios S, Reyes P, Martinez J. Mesenchymal stem cells from osteoporotic patients produce a type I collagen-deficient extracellular matrix favoring adipogenic differentiation. J Cell Biochem. 2000;79:557-565.

115. Sekiya I, Larson BL, Vuoristo JT, Cui JG, Prockop DJ. Adipogenic differentiation of human adult stem cells from bone marrow stroma (MSCs). J Bone Miner Res. 2004;19:256-264.

116. Aubin JE, Bone stem cells. J Cell Biochem.1998;Suppl 30-31:73-82.

117. Cohen PG. Aromatase, adiposity, aging and disease. The hypogonadalmetabolic-atherogenicdisease and aging connection. Med Hypotheses. 2001;56:702-708.

118. Martin RB, Zissimos SL. Relationships between marrow fat and bone turnover in ovariectomized and intact rats. Bone. 1991;12: 123-131.

119. Martin RB, Chow BD, Lucas PA. Bone marrow fat content in relation to bone remodeling and serum chemistry in intact and ovariectomized dogs. Calcif Tissue Int. 1990;46:189-194.

120. Cheleuitte D, Mizuno S, Glowacki J. In vitro secretion of cytokines by human bone marrow: Effects of age and estrogen status. J Clin Endocrinol Metab.1998;83:2043-2051.

121. Moerman EJ, Teng K, Lipschitz DA, Lecka-Czernik B. Aging activates adipogenic and suppresses osteogenic programs in mesenchymal marrow stroma/stem cells: The role of PPAR-gamma2 transcription factor and TGF-beta/BMP signaling pathways. Aging Cell. 2004;3: 379-389.

122. Kajkenova O, Lecka-Czernik B, Gubrij I, et al. Increased adipogenesis and myelopoiesis in the bone marrow of SAMP6: a murine model of defective osteoblastogenesis and low turnover osteopenia. J Bone Miner Res. 1997;12:1772-1779.

123. Duque G, Macoritto M, Kremer R. Vitamin D treatment of senescence accelerated mice (SAM-P/6) induces several regulators of stromal cell plasticity. Biogerontology. 2004;5:421-429.

124. Logan CY, Nusse R. The Wnt signaling pathway in development and disease. Annu Rev Cell Dev Biol. 2004;20:781-810.
125. Ross SE, Erickson RL, Gerin I. Microarray analyses during adipogenesis: Understanding the effects of Wnt signaling on adipogenesis and the roles of liver $\mathrm{X}$ receptor $\{$ alpha $\}$ in adipocyte metabolism. Mol Cell Biol. 2002;22:5989-5999.

126. Bennett CN, Ross SE, Longo KA. Regulation of Wnt signaling during adipogenesis. J Biol Chem. 2002;277:30998-31004.

127. Gong Y, Slee RB, Fukai N. LDL receptor-related protein 5 (LRP5) affects bone accrual and eye development. Cell. 2001;107: 513-523.

128. Boyden LM, Mao J, Belsky J. High bone density due to a mutation in LDL-receptor-related protein 5. $N$ Engl J Med. 2002;346: 1513-1521.

129. Kato M, Patel MS, Levasseur R. Cbfa1-independent decrease in osteoblast proliferation, osteopenia, and persistent embryonic eye vascularization in mice deficient in Lrp5, a Wnt coreceptor. $J$ Cell Biol. 2002;157:303-314.

130. Little RD, Carulli JP, Del Mastro RG. A mutation in the LDL receptorrelated protein 5 gene results in the autosomal dominant high-bonemass trait. Am J Hum Genet. 2002;70:11-19.

131. Bennett CN, Longo KA, Wright WS Regulation of osteoblastogenesis and bone mass by Wnt10b. Proc Natl Acad Sci U S A. 2005;102: 3324-3329.

132. Liu J, Farmer SR. Regulating the balance between peroxisome proliferator-activated receptor gamma and beta-catenin signaling during adipogenesis. A glycogen synthase kinase 3 beta phosphorylationdefective mutant of beta-catenin inhibits expression of a subset of adipogenic genes. J Biol Chem. 2004;279:45020-45027.

133. Zhou S, Eid K, Glowacki J. Cooperation between TGFbeta and Wnt pathways during chondrocyte and adipocyte differentiation of human marrow stromal cells. J Bone Miner Res. 2004;19:463-470.

134. Abdallah BM, Jensen CH, Gutierrez G, Leslie RG, Jensen TG, Kassem M. Regulation of human skeletal stem cells differentiation by Dlk1/Pref-1. J Bone Miner Res. 2004;19:841-852.

135. Kindblom JM, Gevers EF, Skrtic SM. Increased adipogenesis in bone marrow but decreased bone mineral density in mice devoid of thyroid hormone receptors. Bone. 2005;36:607-616.

136. Kajkenova O, Lecka-Czernik B, Gubrij I. Increased adipogenesis and myelopoiesis in the bone marrow of SAMP6, a murine model of defective osteoblastogenesis and low turnover osteopenia. J Bone Miner Res. 1997;12:1772-1779.

137. Duque G, Macoritto M, Dion N, Ste-Marie LG, Kremer R. $1,25(\mathrm{OH}) 2 \mathrm{D} 3$ acts as a bone-forming agent in the hormoneindependent senescence-accelerated mouse (SAM-P/6). Am J Physiol Endocrinol Metab. 2005;288:E723-E730.

\section{Publish your work in this journal}

Diabetes, Metabolic Syndrome and Obesity: Targets and Therapy is an international, peer-reviewed open-access journal committed to the rapid publication of the latest laboratory and clinical findings in the fields of diabetes, metabolic syndrome and obesity research. Original research, review, case reports, hypothesis formation, expert opinion and commentaries are all considered for publication. The manuscript management system is completely online and includes a very quick and fair peer-review system, which is all easy to use. Visit http://www.dovepress.com/testimonials.php to read real quotes from published authors. 